\section{Some Practical and Biotechnological Methods for Improving Reproduction Traits in Sheep}

\author{
Gabriella N. Dankó \\ University of Debrecen, Centre for Agricultural Sciences, \\ Faculty of Agricultural Sciences, \\ Department of Animal Physiology and Hygiene, Debrecen
}

\section{SUMMARY}

However, reproduction in sheep is seasonal, many breeds of sheep are able to mate not only in autumn, but out-of-season as well. The main factor determining seasonality is the photoperiod, but other factors can influence reproductive pattern, such as genetics, management practices and social cues. The fertility of spring and early summer breeding is usually lower; this imposes the need for alternative methods (e.g. hormonal treatments, biotechnological practice), to increase the conception rate.

The author summarize the main practical techniques and biotechnological methods for controlling reproduction completed with some own experimental results in connection with different topics.

\section{OESTRUS SYNCHRONIZATION}

The methods of oestrus synchronization can be classified as natural (ram effect) and pharmacological. The pharmacological methods are more effective, however more expensive.

One of the main advantages of these methods, they can be administered to induce and/or synchronize oestrus, and the time of AI can be planned exactly.

\subsection{Ram effect}

Rams can stimulate gonadotropin secretion and ovulation of ewes through chemosensory cues due to the pheromones present in the ram's wool and wax secretion. Male effect leads to a rise of the $\mathrm{LH}$ concentration in females within a few minutes and later to an increased LH pulse frequency, which is a prerequisite for the stimulation of follicular growth and oestrogen secretion (Claus et al., 1990). Ram or male effect involves the introduction of rams to ewes, which have been previously isolated from males for several weeks but it is not effective for females in deep anoestrus. This method can improve the efficacy of oestrus synchronisation or induction as well.

\subsection{Pharmacological methods}

Prostaglandin $\boldsymbol{F 2} \alpha$ and its analogues are available in injectable form. As its cause the regression of corpus luteum (CL), prostaglandins are not relevant to controlled sheep reproduction during the anoestrus period (i.e. shortage of CL) (Gordon, 1999). Due to the fact that CL is only responsive to prostaglandins between days 5-14 of the oestrus cycle, two injections, 10-14 days apart, are required for optimum synchronization.

In comparative studies, prostaglandins have been shown to be less effective in synchronizing oestrus than progestagen pessaries (Hackett et al., 1981; Henderson et al., 1984).

Melatonin, a hormone produced by the pineal gland, is considered to be the photoperiod mediator affecting the secretion of hormones by the pituitary gland. Melatonin is responsible for transfer of daylength information to the hypothalamic-pituitary axis (Arendt, 1986), it is secreting during the dark period of the day.

In some countries, melatonin has been marketed as a slow release implant. Apparently, elevated blood concentrations of melatonin for at least five weeks are necessary to advance the season, the treatment have been used associated with other techniques, as light-program (short-day imitation) ram effect or sponges.

The progestagen-based intravaginal sponge treatments are the most appropriate hormonal technique for sheep fertility control. In cyclic females acts by suppressing the pre-ovulatory pituitary release of gonadotropins and, therefore, follicular growth and ovulation. After withdrawal of the progestagen source, the increasing amounts of gonadotropin released lead to oestrus and ovulation. Progestagens can be administered by different methods (sponge, injection, implants), by several routes (intravaginal, i.m., s.c.) and at different doses. Sponges are impregnated with 30 or $40 \mathrm{mg}$ of flurogestone acetate (FGA) or $60 \mathrm{mg}$ of medroxyprogesterone acetate (MAP). They are inserted into the vagina with the aid of an applicator. The progestagen must be supplemented with follicle stimulating treatments pregnant mare serum gonadotropin (PMSG) to induce follicular growth, oestrus and ovulation; the dose of PMSG must be adapted to breed, season, flock, age and physiological status of the animals (Neils, 1997). Ewes begin to come into oestrus from around 24 to 48 hours after sponge removal. The treatment schedules for FGA sponges are shown in Table 1.

In the 1980s in New Zealand an intravaginal device for oestrus and ovulation control in sheep was developed. It is called "CIDR", controlled internal drug releasing dispenser, an intravaginal device constructed of a progesterone-impregnated silicon elastomere (Welch et al., 1984). The advantage of the CIDR, it is progesterone based intravaginal devices, there is not synthetic progestagen (FGA, MAP) in it. According to literature's dates the synthetic 
progestagens has depressing effect on adrenocortical function (details: 1.2.1. chapter). A further point, which is often emphasized, is, that withdrawal of CIDRs is not accompanied by the fluid discharge seen at sponge withdrawal (Carlson et al., 1989).

Table 1

Treatment schedules for FGA sponges

\begin{tabular}{|l|l|r|r|r|}
\hline \multirow{2}{*}{ Females } & Season & $\begin{array}{c}\text { FGA } \\
\text { (mg) }\end{array}$ & $\begin{array}{c}\text { Length of } \\
\text { treatment } \\
\text { (d) }\end{array}$ & $\begin{array}{c}\text { Dose of } \\
\text { PMSG } \\
\text { (IU) }\end{array}$ \\
\hline \multirow{3}{*}{ Ewes } & Anoestrus & 30 & 12 & 400 to 600 \\
\cline { 2 - 5 } & $\begin{array}{l}\text { Oestrus } \\
\text { season }\end{array}$ & $30-40$ & $12-14$ & 300 to 500 \\
\hline \multirow{2}{*}{ Ewe lambs } & Anoestrus & 40 & 14 & 350 to 500 \\
\cline { 2 - 5 } & $\begin{array}{l}\text { Oestrus } \\
\text { season }\end{array}$ & 40 & 14 & 250 to 400 \\
\hline
\end{tabular}

Source: Neils, 1997

\subsubsection{The effects of the synthetical gestagens on the adrenocortical function}

The effects of the synthetical gestagens on the adrenocortical function were observed mostly in pets (Selman et al., 1997; Watson et al., 1989). Based upon these results it is required to do functional tests of adrenocortical hormone synthesis of farm animals, because the synthetical gestagens is widely used in these species (for estrus synchronization and estrus induction) as well, however they may influence the cortisol synthesis.

Our labor group ${ }^{1}$ studied the effects of the fluorogeston-acetat (FGA, synthetic progestin) on the adrenocortical function of the ewes (N. DankóKulcsár, 2002).

On the Prolific Merino sheep Farm of Debrecen University, in Kismacs, $n=10$ Prolific Merino ewes were treated with FGA-contained sponges (40 mg flurogestone acetate, Chronogest for sheep ${ }^{\mathrm{TM}}$, Intervet, Booxmer, Holland) for 14 days. We inserted one sponge into the vagina of 5 ewes and two sponges were inserted into 5 ewe's (so the FGA source was double, $80 \mathrm{mg}$ in this case).

To investigate the changes of the adrenocortical function for cortisol responses, exogenous adrenocorticotropic hormone $\left(60 \mu \mathrm{g}{ }_{1-24} \mathrm{ACTH}-\mathrm{t}\right.$ Cortrosyn inj., Organon) was injected. The cortisol concentration of the plasma was detected (1) before the FGA treatment (2) on the day of sponge removal (3) 14 days after the sponge removal by radioimmunoassay (RIA).

The results are shown on the Figure 1. Lower basal cortisol concentrations and the suppression of the cortisol responses after ACTH administration were most pronounced during flurogeston treatment. Adrenal suppression did not exist two weeks later when flurogeston dosage ceased.

\footnotetext{
${ }^{1}$ Szent István University Faculty of Vet. Dept. of Obst. and Repr. Leader: Prof. Huszenicza Gyula

Univ. of Debrecen Faculty of Agr. Dept. of Animal Phys. and Anim. Health Leader: Dr. Magyar Károly
}

It is concluded that FGA suppresses the adrenocortical function, but the adrenocortical response to ACTH stimulation returns to the pretreatment level within two weeks, so this effect is reversible. There is no significant difference between dose (40 mg or $80 \mathrm{mg}$ ) effects.

Figure 1: The plasma cortizol levels before and after FGA treatment (after ACTH stimulation)

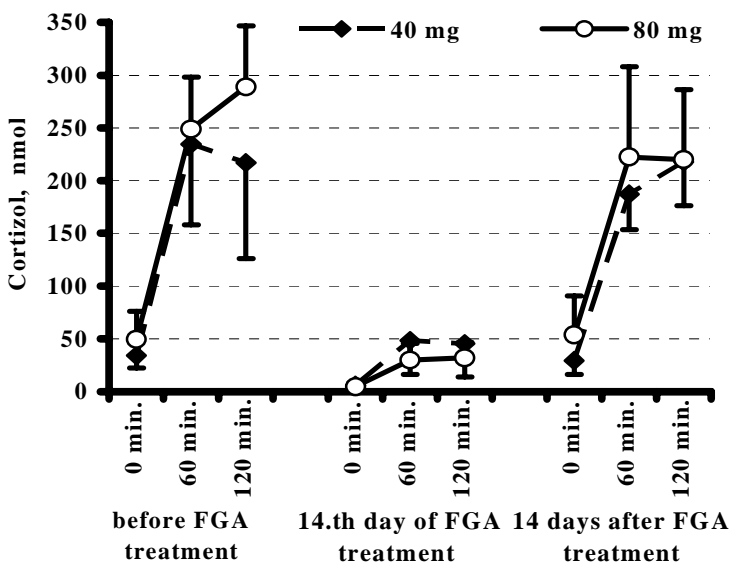

\section{FLUSHING}

Although, the effects of diet on reproduction are poorly understood, it is known that body fat content (body condition) directly affects on hypothalamic activity and GnRH secretion and that effects on performance are mediated by changes in ovarian hormones or in hypothalamic-pituitary sensitivity to ovarian hormones (Gordon, 1999).

Flushing refers to the practice of having ewes on a rising plane of nutrition before mating.

It is equally useful to provide the males with improved nutrition starting 6-8 weeks before they are required for semen collection or mating. Supplementary feeding of rams takes $0,5-0,7 \mathrm{~kg}$ seed mixture/head/day, the ewes receive $0,3-0,4$ $\mathrm{kg} /$ head/day seed mixture and hay (Lucerne) ad libitum, respectively. There can be maize, oat, rye in the seed mixture and the germinated seeds are recommended as well in order to activate the hormonal function of the reproductive organs. The flushing period of ewes usually starts 3 weeks before the mating period.

\section{FOLLOWING UP THE OVARIAN FUNCTION}

For following up the ovarian function, assaying progesteron ( $\mathrm{P} 4)$ levels in blood is a traditional method in animal husbandry. Collection of blood, however, is painful and stressful therefore methods of fecal steroid examination have been developed for assessing endocrine status. The latter method is based on the phenomenon that certain metabolites of P4 (first of all its various 20-oxo-, 20 $\alpha-\mathrm{OH}-, 20 \beta-$ 
$\mathrm{OH}$-, and $5 \alpha$ - or 5 $5 \beta$-pregnane derivatives) are excreted with the bile through the gastrointestinal tract (Schwarzenberger et al., 1996).

In a study (Kulcsár et al., 2000), we examined the ovarian function of Prolific Merino ewes in the outof -season (springtime) reproductive period by RIA and ELISA hormonal analysis of the blood and faces as well. Based on the blood plasma progesterone level we established, that in out-of -season (AprilMay) breeding period $45 \%$ of the examined Prolific Merino ewes had cyclical ovarian function $\left(\mathrm{P}_{4} \geq 1,00\right.$ $\mathrm{nmol} / \mathrm{l})$. The acyclical ones gave good reaction for cyclus-induction, based on the laparoscopic ovulation rate examination dates ( $92 \%$ of the ewes had CL) however, the precondition of this reaction is to satisfy the energy-requirement of the ewes.

There is close connection between plasma progesteron level ( $\mathrm{ppl}$ ) and gestagen metabolit level (gml) of feces by the examination of lineal-regression method $(\mathrm{r}=0,816 ; \mathrm{P}<0.01)$. If we consider the evidence of lutheal work the $\mathrm{ppl} \geq 1,00 \mathrm{nmol} / 1$ and $\mathrm{gml}$ of feces $\geq 5,00 \mathrm{nmol} / \mathrm{g}$ respectively than the basic on the results of the examined samples we came the same conclusion about CL (Figure 2).

The determination of fecal gestagen metabolites is a useful technique in taking care of sheep reproduction, because the plasma progesterone level and the fecal gestagen metabolite level give nearly the same results and suitable to determine of the cyclical or acyclical status of the ewe.

Figure 2: The plasma progesteron level and the fecal gestagen metabolit level as a function of corpus luteum on the seventh day after $\mathrm{AI}$

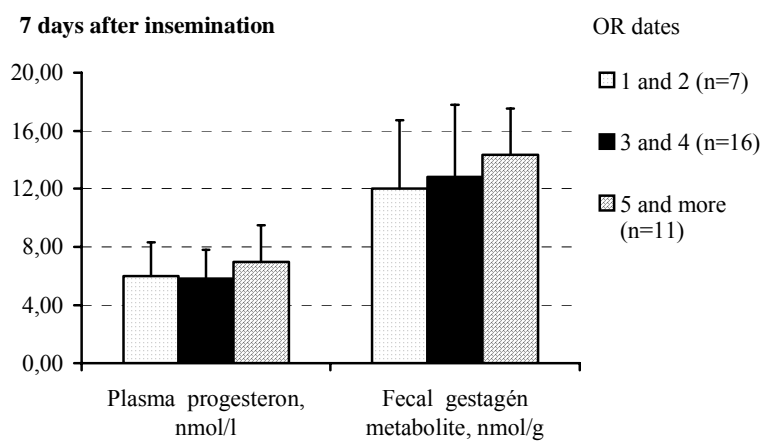

\section{ARTIFICIAL INSEMINATION}

Although the techniques for artificial insemination of sheep using fresh-extended semen have been available for some time, use of frozen semen has not been wide spread. The position and shape of the folds at the entrance to the cervix vary considerably between animals, and deposition of semen deeper than $1 \mathrm{~cm}$ into the cervical canal is seldom possible. The cooling-freezing-thawing procedure is a trauma for the spermatozoa, ultrastructural, biochemical and functional changes happen in their structure and the capacitation may occur too early (Salamon and Maxwell, 1995). For these reasons the fertility is not sufficient when thawed semen is deposited in the vagina or into the uterus via cervix.

Laparoscopy has evolved as one of the least invasive techniques depositing frozen-thawed semen in the uterus of sheep, directly the conception rate of this method is $50-60 \%$ (Salamon, 1976; Magyar, 1998).

\section{PREGNANCY DIAGNOSIS}

Pregnancy diagnosis can help to increase efficiency of sheep reproduction. The farmer can benefit from early re-breeding of non-pregnant ewes, and from the separated feeding of pregnant and nonpregnant animals. Of the several methods available for pregnancy diagnosis in sheep ultrasoundscanning devices are particularly interesting because of their accuracy and reliability. Real time ultrasound scanning can detect pregnancy as early as 23 days of gestation, by the rectal route, and 40 days, by the external trans-abdominal route. Doppler and amplitude-depth (A-mode) ultrasound are a cheaper alternative in the second half of gestation (Gordon, 1999).

\section{CONTROL OF LAMBING}

As a follow on to controlled mating, controlled lambing by an appropriate induction agent may occasionally have practical appeal. The timing of lambing may be influence by exogenous hormones. The administration of progesterone, with its wellknown inhibitory action on uterine motility, might possibly be employed to delay parturition. Betamethazone and dexamethazone, used at a dose rate of 8 to $16 \mathrm{mg} \mathrm{im}$. inj., are the most commonly used corticosteroides results in completion of lambing between 26 and 62 hours of treatment (Gordon, 1999).

The use of estrogen as the agent for synchronizing lambings in sheep could be hazardous if the farmer is not quite certain of their conception dates (Cahill et al., 1976; Robinson, 1980). Ewes bearing twins or multiple foetus can suffer from pregnancy toxaemia at the end of pregnancy because of poor nutrition, so it is beneficial for ewes to be separate during the final trimester of pregnancy and fed according to the number of lambs they are carrying. Administration of oxitocin is a useful technique to fasten the birth process.

It is rare for the death of the lamb to occur prior the start of parturition, the generally accepted incident of antenatal death is about $2 \%$. Survival of the live-born lamb depends mainly on its ability to withstand environmental stress cold and starvation. However care, supervision and management at lambing can make the vital difference in reducing lamb losses. 


\section{INCREASE THE FREQUENCY OF LAMBING}

A further step in management systems aimed to improve reproductive performance is the intensification of the rythm of lambing. The object of this procedure is to shorten the non-productive intervals (lambing to conception interval). One of the most common techniques is the " 3 lambing in 2 years" system (Table 2).

Illustration of the " 3 lambing in 2 years" systerm

\begin{tabular}{|c|c|c|c|c|c|c|c|c|c|c|c|c|}
\hline Year 1 & Jan & Feb & Mar & Apr & May & June & July & Aug & Sept & Oct & Nov & Dec \\
\hline Group A & \multicolumn{3}{|c|}{ Mating } & & & \multicolumn{2}{|c|}{ Lambing } & \multicolumn{3}{|c|}{ Mating } & & \\
\hline Group B & \multicolumn{2}{|c|}{ Lambing } & & \multicolumn{2}{|c|}{ Mating } & & & & \multicolumn{2}{|c|}{ Lambing } & & \\
\hline Year 2 & Jan & Feb & Mar & Apr & May & June & July & Aug & \multirow{2}{*}{\multicolumn{2}{|c|}{\begin{tabular}{l|l} 
Sept & Oct \\
Lambing
\end{tabular}}} & Nov & Dec \\
\hline Group A & \multicolumn{2}{|c|}{ Lambing } & & Mat & & & & & & & & \\
\hline Group B & \multicolumn{2}{|c|}{ Mating } & & & & \multicolumn{2}{|c|}{ Lambing } & & & & & \\
\hline
\end{tabular}

Source: Neils, 1997

However, the capability of different sheep breeds for frequent lambing are not the same. Robinson (1979) observed that the high annual lamb output of the Finn and Finn-cross ewe was not only the result of a large litter size, but also arose from their reduced lambing interval. It is believed to be easier to achieve an increased lambing frequency with sheep normally associated with higher than a low litter size, even though that particular breed is thought to have the merit of an extended breeding season. There is perhaps some support for this in the fact that Booroola Merino ewes continue to show breeding activity when inhibitory seasonal factors have suppressed the normal Merino type (Bindon and Piper, 1976).

\section{INDUCTION OF MULTIPLY BIRTH}

\subsection{Prolific sheep breeds}

The number of ovulated follicles depends on many factors in sheep, e.g. nutrition, season, age of the ewe, but mostly on breed. Using prolific sheep breeds is one of the possibilities to improve the meat production of the sheep flocks.

The Australia's Booroola Merino is one of the four breeds (i.e. Romanov, Finnsheep and D'man) characterized by their exceptional fecundity. The ewes and rams of this breed was donated from a commercial "high fertility" flock run by the Sears brothers of "Booroola", Cooma farm since 1958.

In the ancient breeding program, ewes were selected on litter size records.

The continual migration of genes through the introduced, unselected rams precludes that result and necessitates an alternative hypothesis: The increased mean litter size of the "high fertility" flock resulted from the gradual accumulation of ewes carrying a single copy of a major gene affecting litter size.

The Booroola gene's expression is evidently sexlimited, because the testis growth rate, testis size and total daily production of spermatozoa of ram are similar to those of normal Merinos. In connection the hormonal status, there is some evidence that Booroola ewes have elevated FSH plasma concentrations, which attributed to an ovarian feedback deficiency, probably because the inhibin content of ovary is only one-third that of normal Merino ewes (Bindon, 1984). There were no significant differences in LH content although the FSH/LH ratio between Booroola and control ewes (Robertson et al., 1984).

The Booroola gene is an autosomal mutation, has additive effect for ovulation rate. Normal merino ewes have an average ovulation rate of 1.5 , FecB heterozygous carriers have an OR of 2.9 and the homozygous have average rate of 4.2.

The laparoscopical ovulation rate examinations started in 1980 in Booroola flock and the selection became more effective by this instrument.

The evaluation of molecular genetic examinations in mapping chromosomal regions enables to determine microsatellite markers. The location of a candidate gene controlling the trait can be inferred because of their proximity to linked markers (Cockett et al., 2001). Linkage to FecB locus was first identified with two random sheep microsatellite markers (OarAE 101 and OarHH55), later one more (the BM1329).

For these molecular genetic examinations blood and semen samples were used and DNA was extracted by PCR methods.

In 2001 some researcher group in the world (i.e.: Souza's team in UK or Wilson's team in New Zealand) discover the exact locus of FecB gene on sheep chromoseme 6 .

Souza et al. (2001) examined cDNA and genomic DNA from 20 Booroola genotypes and they found Adenin Guanin amino acids changing. This single point mutation (A in the ++ and $\mathrm{G}$ in $\mathrm{FF}$ animals) results in a change from glutamine on the wild type to arginine in the Booroola animals.

Wilson et al. (2001) and Souza et al. (2001) shows a very strong association with Booroola genotype segregation and the mutation described in Bone Morphogenic Protein 1B Receptor 1B (BMPR $1 \mathrm{~B})$ gene. BMPR-1B was expressed in the ovary and in situ hybridization revealed its specific location to the oocyte and the granulosa cell.

FecB allel is being integrated into a number of sheep breeds in many countries by classical backcross scheme in order to increase productivity. 
The Prolific Merino, introduced to Hungary as a new breed in 1992, results form crossing the prolific gene carrier Booroola Merino rams with the local Merino breed. Between 1998 and 199321 Prolific Merino rams and 6 thousand dose of frozen semen from 33 rams were imported from New Zealand by leadership of Veress László, professor of University of Debrecen Faculty of Agronomy.

The nucleus herd of the breed, consisting of 200 ewes is kept in Debrecen the farm of University of Debrecen. The ewes had been selected for homosygosity of the FecB gene, by laparoscopically OR control (Magyar et al., 1999).

At the end of the $1990^{\text {th }}$ years the microsatellite markers (OarAE101 and BM1329) of the herd were controlled (Árnyasi et al., 2001). However, these examinations were not so effective to determine genotype as laparascopic OR control.

The resounding success was the determination of the exact locus of FecB gene on sheep chromosome 6. From the end of 2002 year it is possible to determine the genotype (homozygous: FF, heterozygous: $\mathrm{F}+$, or not carrier: ++ ) in Hungary as well, from blood or semen sample. We do these examinations in the Animal Breeding and Feeding Resource Institute in Herceghalom and a new lab is being equipped in Debrecen on University of Agriculture.

\subsection{Flushing}

The increase of energy levels during a short period allows an increased ovulation rate (Downing and Scaramuzzi, 1991). Oldham and Lindsay (1984) found, that short-term (6-9 days) supplementation of the ewe's diet with high protein lupin grains was capable of increasing ovulation rates (OR) by some $20-30 \%$. Nottle et al. (1987) suggested that increase in OR in response to such short term lupin-feeding may be mediated by increases in FSH secretion rate in the luteal phase.

\subsection{Endocrinological flushing}

The "endocrinological flushing" means to give exogen "push" for hormone levels that affect the follicular development. As it causes an increase in OR it's a hormonal induction of multiply birth. Above (chapter 1.2) mentioned PMSG, otherwise known as equine chorionic gonadotropin (eCG) is the most common product used. The dose of PMSG required depends on many factors. During the nonbreeding season treatment is essential and if higher doses are given (500-1000 IU), results an increase in litter size. Typical responses following $750 \mathrm{IU}$ of PMSG results in a litter size of 1,6-1,7 (Gordon, 1983).

In theory, $\boldsymbol{F S H}$ could be used as an alternative to PMSG to increase ovulation rate. Their mechanism of action would be similar. FSH, however has a short half-life, thus must be injected twice daily during treatment.

Gong et al. (1994) investigated the effect of recombinant bovine growth hormone (rBST) on follicle development. They found that such treatment significcaly increase the small follicle population and concluded that rBST and/or insulin-like-growth factor (IGF)-I had a stimulatory effect on the early stage of ovarian folliculogenesis.

Findlay and Cummin (1976) administrated $\boldsymbol{G n R H}$ analogue about day 12 of the cycle, which increased mean ovulation rate by more than $20 \%$.

Active immunization against potentially important hormones has been widely used in research, some authors reported on the use of multisteroides immunizations. In Australia for example Wilson et al. (1990) reported that treatment with androstenedione + testosteron + oestrone resulted in slightly better reproductive performance than treatment with the androstenedione vaccines.

While LH and oestradiol concentration continue to rise during the follicular phase, FSH level falls during the mid-follicular phase due to the inhibitory effects of oestradiol and inhibin on the pituitary. Much research has been directed towards developing inhibin immunization treatment, Boland et al. (1994) found higher ovulation rate and litter size in treated ewes than in the untreated controls.

Passive immunization against inhibin peptide has been dealt with by Kusina et al. (1995); the antibody was injected i.m. $48 \mathrm{~h}$ prior to CIDR withdrawal and increased OR in a dose-related manner.

Manipulation of reproductive seasonality requires knowledge of the physiological process being manipulated, a comprehensive management program including animal nutrition, husbandry and welfare in addition to hormonal treatments is often required.

\section{REFERENCES}

Arendt, J. (1986): Role of the pineal gland and melatonin in seasonal reproductive function in mammals. Oxford Rev. of Repr. Biol., 8. 266-32.

Árnyasi, M.-Zsolnai, A.-Jávor, A.-Fésüs, L.-Dankó N.G.-Magyar, K.-Dohy, J. (2001): Possibility of MAS for FecB gene in the Hungarian prolific merino sheep. Prospects for the Agriculture of the $3^{\text {rd }}$ Millenium, International Symposium, 2001. Oct. 2527 Kolozsvár

Bindon, B. M. (1984): Reproductive biology of the Booroola Merino sheep. Aust. J. Biol. Sci., 3. 163-189.
Bindon, B. M.-Piper, L. R. (1976): Assessment of new and traditional techniques of selection for reproduction rate. Proc. Int. Congr. on Sheep Breed (Muresk) 357-371.

Boland, M. P.-Sunderland, S. J.-Williams, D. H.-Kane, M.Headon, D. R.-Roche, J. F. (1994): Effect of immunisation of ewes against $\times 1$ 1-26 inhibin fragment of antibody titres, ovulation and lambing rate. Anim. Repr. Sci., 34. 241-251.

Cahill, L. P.-Knee, B. W.-Lawson, R. A. S. (1976): Induction of parturition in ewes with a single injection of oestradiol benzoate Theriogenology, 5. 289-294. 
Carlson, K. M.-Pohl, H. A.-Marcek, J. M.-Muser, R. K.-Wheaton, J. E. (1989): Evaluation of progesterone controlled internal drug release dispensers for synchronization of oestrus on sheep. Anim. Repr. Sci., 18. 2005-218.

Claus, R.-Over, R.-Dehnhard, M. (1990): Effect of Male Odour on LH Secretion and the Induction of Ovulation in Seasonally Anoestrous Goats. Anim. Repr. Sci., 22. 27-38.

Cockett, N. E.-Shay, T. L.-Smit, M. (2001): Analysis of the sheep genome Physiological Genomics, 7. 69-78.

Downing, J. A.-Scaramuzzi, R. J. (1991): Nutrient effects on ovulation rate, ovarian function and the secretion of gonadotrophic and metabolic hormones in sheep. J. Reprod. Fert., Suppl., 43. 209-227.

Findlay, J. K.-Cummin, I. A. (1976): Increase in ovulation rate in sheep following administration of an LH-RH analogue. Bil. of Repr., 15. 115-117.

Gong, J. G.-Campbell, B. K.-McBride, D.-Webb, R. (1994): The effect of recombinant bovine somatotropin $(\mathrm{rGH})$ on ovarian follicular population in mature ewes. Journal of Repr. and Fert. Abstr. Series, 13. 9-10.

Gordon, I. (1983): Controlled breeding in farm animals. Pergamon Press, Oxford, Chapter, 10-19.

Gordon, I. (1999): Controlled Reproduction in Sheep and Goat. CAB International, ISBN:0851991157

Hackett, A. J.-Robertson, H. A.-Penner, P.-McLaughlin, G. R. (1981): Comparison of two methods of synchronizing oestrus and subsequent lambing in a commercial sheep flock. Canadian J. of Anim. Sci., 61. 67-72.

Henderson, K. M.-Downing, J. M.-Beck, N. F. G.-Lees, J. L. (1984): Oestrus synchronization in ewes. A comparison of prostaglandin F2 $\alpha$ than salt with a progestagen pessary. Anim. Prod., 39. 229-233.

Kulcsár, M.-Novotni-Dankó, G.-Becskey, Cs.-Magi, Zs.-Kátai, L.Solti, L. (2000): Determination of gestagen metabolites in fecal samples for following up the ovarian activity in small ruminants. Proc. of $4^{\text {th }}$ Annual Conference of the European Society for Domestic Animal Reproduction (Prague, Czech Republic, 23-25 Nov, 2000), published in the ESDAR Newsletter, 5. 43.

Kusina, N. T.-Meyer, R. L.-Carlson, K. M.-Wheaton, J. E. (1995): Effects of passive immunization of ewes against an ihibinpeptide on gonadotrophin levels, ovulation rate and prolificacy, Biol. of Repr., 52. 878-884.

Magyar, K. (1998): Laparoszkópos módszerek alkalmazása a szapora merinó tenyészetben. Állattenyésztés és Takarmányozás, Juhtenyésztési különszám, 47. 167-172.

Magyar, K.-Veress, L.-Tasi, Zs.-Pécsi, T.-Babik, S.-Horváth, I. (1999): Zootechnical and genetic aspects of a prolific merino program. Act. Vet. Hun. 47. 1. 17-31.

Neils, P. C. (1997): Compendium of Animal Reproduction. Intervet International B.V. ISBN:9080188654

Nottle, M. B.-Setchell, B. P.-Seamark, R. F. (1987): Short-term supplementation with lupin gain increases FSH in the ovariectomized, eostradiol-implanted ewe. Proc. of Australian Soc. Repr. Biol., 19. 37.
Novotniné, Dankó G.-Kulcsár, M. (2002): A fluorogeszton kezelés mellékvesekéreg-múködésre gyakorolt hatása juhban. 13. Magyar Buiatrikus Kongresszus, Hajdúszoboszló, Okt.10-12 Proceedings, 162-166.

Oldham, C. M.-Lindsay, D. R. (1984): The minimum period of intake of lupin grain required by ewes to increase their ovulation rate when grazing dry summer pasture. Univ. Press, Cambridge, 274-275.

Robertson, D. M.-Ellis, S.-Foulds, L. M.-Findlay, J. K.-Bindon, B. M. (1984): Pituitary gonadotrophins in Booroola and control Merino sheep. Reprod. Fertil., 71. 1. 189-197.

Robinson, J. J. (1979): Intensive systems. In: Management and Diseases of Sheep. Commonwealth Agr. Bur. Slough, 431446.

Robinson, T. J. (1980): Programmed year-round sheep breeding. Australian Journal of Exp. Agr. and Anim. Husb., 210. 667673.

Salamon, I.-Maxwell, W. M. C. (1995): Frozen storage of ram semen II. Causes of low fertility after cervical insemination and methods of improvement Anim. Repr. Sci., 38. 1-36.

Salamon, S. (1976): Artificial Insemination of sheep. Publicity Press, Chippendale, N.S.W. 2006.

Schwarzenberger, F.-Möstl, E.-Palme, R.-Bammberg, E. (1996): Fecal steroid analysis for non-invasive monitoring of reproductive status in farm, wild and zoo animals. Anim. Reprod. Sci., 42. 515-526.

Selman, P. J.-Mol, J. A.-Rutteman, G. R.-Garderen, E.-van, Ingh, T.S.G.A.M. van den, Rijnberk, A. (1997): Effects of progestin administration on the hypoyhalamic-pituitary-adrenocortical axis and glucose homeostasis in dogs. Journal of Reproduction and Fertility Supplement, 51. 345-354.

Souza, C. J. H.-MacDougall, C.-Campbell, B. K.-McNeilly, A. S. (2001): The Booroola ( $\mathrm{FecB}$ ) phenotype is associated with a mutation in the bone morphogenic receptor type $1 \mathrm{~B}$ (BMPR1B) gene Journal of Endocr. 169 R1-R6.

Watson, A. D. J.-Church, D. B.-Emslie, D. R.-Middleton, D. J. (1989): Comparative effects of proligestone and megestrol acetate on basal plasma glucose concentrations and cortisol responses to exogenous adrenocorticotropic hormone in cats. Research in Veterinary Science, 147. 374-376.

Welch, R. A. S.-Andrews, W. D.-Barnes, D. R.-Bremner, K.Harvey, T. G. (1984): CIDR dispenser for oestrus and ovulation control in sheep. Proc. of the $10^{\text {th }}$ Int. Congr. Anim. Repr. and AI (Illionis) 3. 354.

Wilson, P. A.-Cox, R. I.-Wong, M. S. F.-Paull, D. R. (1990): Multi-steroid immunization - a practical treatment to increase fecundity in Merino ewes. Proc. of Australian Soc. of Animal Production, 18. 432-435.

Wilson, T.-Xi-Yang Wu-Juengel, J. L.-Ross, I. K.-Lumsden, J. M.Lord, E. A.-Dodds, K. G.-Walling, G. A.-McEwan, J. C.O'Connel, A. R.-McNatty, P. K.-Mongomery, G. W. (2001): Highly Prolific Booroola Sheep Have a Mutation in the Intracellular Kinase Domain of Bone Morphogenetic Protein IB receptor (ALK-6) That Is Expressed in Both Oocytes and Granulosa Cells. Biol. of Repr., 64. 1225-1235. 